\title{
Grafting Effects on Vegetable Quality
}

\author{
Angela R. Davis ${ }^{1}$ and Penelope Perkins-Veazie \\ U.S. Department of Agriculture, Agricultural Research Service, South Central Agricultural \\ Research Laboratory, P.O. Box 159, Highway 3 West, Lane, OK 74555 \\ Richard Hassell \\ Clemson University, CREC, 2700 Savannah, Highway, Charleston, SC 29414 \\ Amnon Levi \\ U.S. Vegetable Laboratory, USDA, ARS, 2700 Savannah Highway, Charleston, SC 29414 \\ Stephen R. King \\ Vegetable Fruit Improvement Center, Department of Horticultural Sciences, Texas A\&M University, \\ College Station, TX 77843-2133 \\ Xingping Zhang \\ Syngenta Seeds, 21435 County Road 98, Woodland, CA 95695 \\ Additional index words. Carotenoid, soluble solids, cucurbit, tomato, flavor, $\mathrm{pH}$
}

\begin{abstract}
Vegetable grafting began in the 1920s using resistant rootstock to control soilborne diseases. This process is now common in Asia, parts of Europe, and the Middle East. In Japan and Korea, most of the cucurbits and tomatoes (Lycopersicon esculentum Mill.) grown are grafted. This practice is rare in the United States, and there have been few experiments to determine optimal grafting production practices for different geographical and climatic regions in America. This is beginning to change as a result of the phase out of methyl bromide. The U.S. cucurbit and tomato industries are evaluating grafting as a viable option for disease control. Because reports indicate that type of rootstock alters yield and quality attributes of the scion fruit, some seed companies are investigating grafting as a means to improve quality. It has been reported that $\mathrm{pH}$, flavor, sugar, color, carotenoid content, and texture can be affected by grafting and the type of rootstock used. Reports vary on whether grafting effects are advantageous or deleterious, but it is usually agreed that the rootstock/scion combination must be carefully chosen for optimal fruit quality. Additionally, it is important to study rootstock/scion combinations under multiple climatic and geographic conditions because many rootstocks have optimal temperature and moisture ranges. This report gives an overview of the effect of grafting on vegetable quality.
\end{abstract}

Reports mentioning quality of vegetables being affected by grafting began as early as the 1940s. Imazu (1949) recommended Cucurbita moschata (Duchesne ex. Poir) as a rootstock for Cucumis melo, because it conferred resistance to Fusarium wilt as well as strong plant vigor, although he reported that this rootstock also caused inferior texture and flavor in grafted 'Honey Dew' (Cucumis melo var. inodorus) fruits. If Cucurbita spp. are used as a rootstock with the melon 'Earl's Favorite', the quality of the fruit netting is

We thank Amy Helms, Salvador Lopez-Galarza, Yoshiteru Sakata, Sang-Gyu Lee, Zhanyong Sun, J. V. Maroto, and A. Miguel for help with literature and references.

Mention of trade names or commercial products in this article is solely for the purpose of providing specific information and does not imply recommendation or endorsement by the U.S. Department of Agriculture. All programs and services of the U.S. Department of Agriculture are offered on a nondiscriminatory basis without regard to race, color, national origin, religion, sex, age, marital status, or handicap. The article cited was prepared by a USDA employee as part of his or her official duties. Copyright protection under U.S. copyright law is not available for such works. Accordingly, there is no copyright to transfer. The fact that the private publication in which the article appears is itself copyrighted does not affect the material of the U.S. Government, which can be freely reproduced by the public.

${ }^{1}$ To whom reprint requests should be addressed; e-mail angela.davis@lane-ag.org. poorer and sugar content decreases by 2 to 3 Brix than those on nongrafted plants (Kamiya and Tamura, 1964). The interspecific hybrid rootstock, 'Shin-tosa' [Cucurbita maxima (Duchense ex. Lam.) $\times$ C. moschata], is resistant to Fusarium wilt but is almost never used for melon in Japan because it causes reduced fruit quality, including low sugar content, alcoholic fermentation, and fibrous flesh (Muramatsu, 1981). Yamasaki et al. (1994) reported that grafting watermelon [Citrullus lanatus (Thunb.) Matsum. and Nakai] to interspecific hybrid squash caused more vigorous growth and resulted in firmer flesh than plants grafted to bottle gourd [Lagenaria siceraria (Molina) Standl.] rootstock and nongrafted watermelon controls. In the same study, grafting to both squash and bottle gourd decreased Brix. A recent study reported off-taste and texture in winter melon (Cucumis melo L. var. inodorus) fruit grown in Greece from some rootstock/ scion combinations (Koutsika-Sotiriou and Traka-Mavrona, 2002). However, Davis and Perkins-Veazie (2005) report that grafting can increase lycopene content and firmness of watermelon flesh. Perkins-Veazie (personal communication) demonstrated that grafting watermelon could increase lycopene and total carotenoids by $20 \%$ and amino acids, especially citrulline, by $35 \%$. Citrulline, a nonessential amino acid, was shown to have vasodilation properties (Lee et al., 1996).

This article gives a general overview of how grafting affects vegetable quality and what quality traits are affected. It is intended to show the importance of careful selection of rootstock/scion combinations to ensure highquality grafted vegetable fruit.

\section{HOW ROOTSTOCKS AFFECT SCIONS}

There are many reasons why rootstocks affect scion fruit quality. The most obvious is rootstock/scion incompatibility, which induces undergrowth or overgrowth of the scion, leading to decreased water and nutrient flow through the grafted union, causing wilting. Incompatibility can be affected by tissue and structure difference, physiological and biochemical characteristics, growing stage of rootstock and scion, phytohormones, and the environment.

Generally, grafting compatibility is related to taxonomic affinity, but there are significant exceptions. Graft incompatibility as reviewed by Andrews and Marquez (1993) is differentiated from graft failure, which often results from environmental factors or lack of skill of the grafter. When grafting conditions have been successfully ensured, graft incompatibility could be attributed to other factors such as failure of rootstock and scion to affect a strong union, failure of the grafted plant to grow, or premature death of either rootstock or scion after grafting. Physiological incompatibility may also occur as a result of lack of cellular recognition, wounding responses, presence of growth regulators, or incompatibility toxins (Andrews and Marquez, 1993). 
Most reports on grafting suggest that changes in the scion are controlled by the rootstock through controlled uptake, synthesis, and translocation of water, minerals, and plant hormones (for a review, see Lee and Oda, 2003). A few studies have explored how the scion is affected by mRNA and protein migrating from the rootstock. RuizMedrano et al. (1999), Xoconostle-Cázares et al. (1999), and Kudo and Harada (2007) showed that mRNA and Golecki et al. (1998) and Gómez et al. (2005) demonstrated that phloem proteins from the rootstock can migrate from the rootstock through the phloem to the scion and accumulate in the phloem and apical tissues. One of these mRNAs is a member of a gene family in which some the members are reported to be involved in apical meristem development (Ruiz-Medrano et al., 1999). Another was shown to change leaf morphology of potato scion when grafted onto transgenic modified tomato rootstock (Kudo and Harada, 2007). Tiedemannand Carstens-Behrens (1994) studied the phloem proteins that differed in cucumber (C. sativus) grafted on figleaf gourd (C. ficifolia) or on pumpkin (C. max$i m a$ ). They found four proteins on sodium dodecylsulfate polyacrylamide gel electrophoresis gels in grafted scions that do not appear in control plants but matched the rootstock phloem protein pattern. Two of the proteins match the phloem protein 1 and phloem protein 2 molecular weight of the rootstock. Ruiz-Medrano et al. (1999) suggest this migration is a novel mechanism likely used to integrate developmental and physiological processes on a whole-plant basis. The phloem proteins role may be in long-distance transport of RNA within plants (Golecki et al., 1998).

\section{INCREASED NUTRIENT UPTAKE}

Grafting influences absorption and translocation of phosphorus, nitrogen, magnesium, and calcium (Gluscenko and Drobkov, 1952; Ikeda et al., 1986; Kim and Lee, 1989; Pulgar et al., 2000; Ruiz et al., 1997). Hu et al. (2006) suggested that improved nutrient uptake in grafted seedlings increases photosynthesis, which is particularly noticeable under less than optimal growing conditions such as weak sunlight and low $\mathrm{CO}_{2}$ content in solar greenhouses during winter months. It has been suggested that these conditions allow grafted plants to produce higher yields, sometimes with improved fruit quality (Xu et al., 2005, 2006; Zhu et al., 2006).

\section{EFFECT OF GRAFTING ON THE PERIOD OF FLOWERING AND HARVEST}

Sex expression and flowering order are controlled by plant hormones. The root-scion combination may alter amounts of hormones produced and their influence on grafted plants organs (Satoh, 1996). Sakata et al. (2007) and Kurata (1976) state that compared with other rootstocks, watermelon grafted

Table 1. Demonstration of how grafting can affect fruit quality of vegetables ${ }^{z}$.

\begin{tabular}{lccccccr}
\hline Crop & Wt or size & Firmness & $\begin{array}{c}\text { SSC or } \\
\text { sweetness }\end{array}$ & $\begin{array}{c}\mathrm{L}^{*} \mathrm{a}^{*} \mathrm{~b}^{*} \\
\text { or color }\end{array}$ & $\mathrm{pH}$ & Vitamin C & Carotenoids \\
\hline Tomato & + & - & - & & 0 & \\
Eggplant & & + & - & 0 & - & + \\
Cucumber & & $+/ 0 /-$ & $+/ 0 /-$ & & - & + & + \\
Watermelon & $+/ 0 /-$ & 0 & $+/ 0 /-$ & 0 & & & + \\
Melon & $+/ 0 /-$ & 0 & & & \\
\hline
\end{tabular}

"An increase in the quality parameter is indicated as a "+", a decrease as a "-", and no change is indicated as a "0". Multiple effects indicate conflicts in the literature.

Data from these sources: Arvanitoyannis et al., 2005; Crinò et al., 2007; Davis and Perkins-Veazie, 2005; Fernández et al., 2004; Muramatsu, 1981; Pogonyi et al., 2005; Traka-Mavrona et al., 2000; TrionfettiNisini et al., 2002; Yamasaki et al., 1994; Yetisir et al., 2003; Zhu et al., 2006.

$\mathrm{SSC}=$ soluble solids content.

onto bottle gourd causes early formation of female flowers. In contrast, flowering is delayed in pumpkin-, bottle gourd-, wax gourd-, and watermelon-grafted watermelon, especially in plants with 'Shintosa'-type rootstocks (Yamasaki et al., 1994). Flowering date affects fruit harvest time, which can have a direct impact on quality.

\section{QUALITY}

Clearly, the scion variety affects final size, yield, and quality of fruit in grafted plants, but rootstock effects can drastically alter these characteristics. There are many conflicting reports on changes in fruit quality resulting from grafting. The differences in reported results may be attributable in part to different production environments, type of rootstock/scion combination used, and harvest date. Because grafting affects flowering and harvest date, it is often difficult to harvest ripe fruit from grafted and nongrafted controls concurrently, further confusing results. Listed subsequently are a few examples of how grafting affects quality.

Abnormal fruit quality issues reported for $C$. melo include reduced fruit soluble solids content, persistent green color in the suture stripe, fruit fermentation, fibrous flesh, and off-taste (Chung, 1995; Kamiya and Tamura, 1964; Koutsika-Sotiriou and Traka-Mavrona, 2002; Lee, 1989; Lee et al., 1998; Muramatsu, 1981).

Abnormal fruit quality issues reported for watermelon include reduced soluble solids content, increased number of yellowish bands in the flesh, insipid taste, poor texture (more fibers), and decreased firmness (Lee and Oda, 2003; Yamasaki et al., 1994). However, others report positive effects of grafting watermelon, including an increase in fruit firmness, Brix, and lycopene content (Davis and Perkins-Veazie, 2005; Salam et al., 2002). Yetisir et al. (2003) reported that quality (Brix, firmness, rind thickness, and fruit shape) of grafted watermelon was greatly affected by grafting, but the results were dependent on the rootstock used, whereas Miguel et al. (2004) found no difference in soluble solids concentration of watermelon fruit from scions grafted to a $C$. maxima $\times$ C. moschata hybrid rootstock compared with controls. Two studies indicate that grafting can increase fruit size in watermelon (Miguel et al., 2004; Salam et al., 2002).
An early report stated that crops that are harvested immature such as cucumber have fewer reported negative quality effects resulting from grafting, although increased firmness and shortening of fruits have been noted (Muramatsu, 1981). However, later reports suggest that different rootstocks affect grafted cucumber quality characteristics such as fruit shape, skin and flesh color and texture, skin smoothness, firmness, rind thickness, and soluble solids content (Choi et al., 1992; Inayama, 1989; Kang et al., 1992; Robinson and Decker-Walters, 1997). Zhu et al. (2006) reported an increase in ascorbic acid content with grafting.

Table 1 demonstrates the inconsistency in published reports on quality effects of grafted vegetables. Breeding programs to select for improved rootstocks seem to have started a trend toward higher-quality fruit from grafted plants. Continued screening of rootstock/ scion combinations and continued rootstock selection will decrease the negative quality aspects for this valuable procedure.

\section{CONCLUSION}

Grafting can affect various quality aspects of vegetables. Rootstock/scion combinations should be carefully selected for specific climatic and geographic conditions. Appropriate selection can help control soilborne diseases and also increase yield and improve fruit quality.

\section{Literature Cited}

Andrews, P.K. and C.S. Marquez. 1993. Graft incompatibility. Hort. Rev. (Amer. Soc. Hort. Sci.) 15:183-232.

Arvanitoyannis, I.S., E.M. Khah, E.C. Christakou, and F.A. Bietsos. 2005. Effect of grafting and modified atmosphere packaging on eggplant quality parameters during storage. Int. J. Food Sci. Technol. 40:311-322.

Choi, J.S., K.R. Kang, K.H. Kang, and S.S. Lee. 1992. Selection of cultivars and improvement of cultivation techniques for promoting export of cucumbers. Res. Rpt., Min. Sci. \& Technol., Seoul, Republic of Korea. p. 74.

Chung, H.D. 1995. Studies on the occurrence causes and prevention of fermentation in melon fruit, Cucumis melo L. var. makuwa Mak. cv. Geumssaragi-euncheon. Res. Rep. Kyungpuk Provincial RDA, Korea.

Crinò, P., C. Lo Bianco, Y. Rouphael, G. Colla, F. Saccardo, and A. Paratore. 2007. Evaluation of rootstock resistance to fusarium wilt and 
gummy stem blight and effect on yield and quality of a grafted 'Inodorus' melon. HortScience 42:521-525.

Davis, A.R. and P. Perkins-Veazie. 2005. Rootstock effects on plant vigor and watermelon fruit quality. Cucurbit Genet. Coop. Rpt. 28:39-42.

Fernández, G., V. Martínez, A. Cerdá, and M Carvajal. 2004. Fruit quality of grafted tomato plants grown under saline conditions. J. Hort. Sci. Biotechnol. 79:995-1001.

Gluscenko, I.E. and A.A. Drobkov. 1952. Introduction and distribution of radioactive elements in grafted plants and their effect on the development of tomato [in Russian]. Izv. Akad. Nauk S.S.R.R. Ser. Biol. 6:62-66.

Golecki, B., A. Schulz, U. Carstens-Behrens, and R. Kollmann. 1998. Evidence for graft transmission of structural phloem proteins or their precursors in heterografts of Cucurbitaceae. Planta 206:630-640.

Gómez, G., H. Torres, and V. Pallás. 2005. Identification of translocatable RNA-binding phloem proteins from melon, potential components of the long-distance RNA transport system. Plant J. 41:107-116.

Hu, C.M., Y.L. Zhu, L.F. Yang, S.F. Chen, and Y.M. Huang. 2006. Comparison of photosynthetic characteristics of grafted and own-root seedling of cucumber under low temperature circumstances. Acta Bot. Boreali-Occidentalia Sinica 26:247-253.

Ikeda, H., O. Shinji, and A. Kazuo. 1986. The comparison between soil and hydroponics in magnesium absorption of grafting cucumber and the effect of increased application of magnesium. Bull. Natl. Veg. Res. Ins. Japan C9:31-41.

Imazu, T. 1949. On the symbiotic affinity caused by grafting among Cucurbitaceous species [in Japanese]. J. Jpn. Soc. Hort. Sci. 18:6-42.

Inayama, M. 1989. Influences and problems of 'bloomless' cucumber [in Japanese]. Yasai Engei Gijyutu 16:7-39.

Kamiya, E. and S. Tamura. 1964. Studies on grafting in muskmelon [in Japanese]. Bull. Shizuoka Pref. Agri. Exp. Stn. 9:79-83.

Kang, K.S., S.S. Choi, and S.S. Lee. 1992. Studies on rootstocks for stable production of cucumber. Kor. Soc. Hort. Sci. 19:122-123 (abstr.).

Kim, S.E. and J.M. Lee. 1989. Effect of rootstocks and fertilizers on the growth and mineral contents in cucumber (Cucumis sativus). Res. Collection, Inst. Food Develop. Kyung Hee Univ., Korea 10:75-82.
Koutsika-Sotiriou, M. and E. Traka-Mavrona. 2002. The cultivation of grafted melons in Greece, current status and prospects. Acta Hort. ISHS 579:325-330.

Kudo, H. and T. Harada. 2007. A graft-transmissible RNA from tomato rootstock changes leaf morphology of potato scion. HortScience 42:225226.

Kurata, H. 1976. Studies on the sex expression of flowers induced by day-length and temperature in pumpkin and watermelon. Mem. Fac. Agr. Kagawa Univ. 29:1-49.

Lee, J. 1989. On the cultivation of grafted plants of cucurbitaceous vegetables. J. Kor. Soc. Hort. Sci. 39:169-179.

Lee, J.M., H.J. Bang, and H.S. Ham. 1998. Grafting of vegetables. J. Jpn. Soc. Hort. Sci. 67:1098-1114.

Lee, J.M. and M. Oda. 2003. Grafting of herbaceous vegetable and ornamental crops. Hort. Rev. (Amer. Soc. Hort. Sci.) 28:61-124.

Lee, T.J.-F., S. Sarwinski, T. Ishine, C.C. Lai, and F.Y. Chen. 1996. Inhibition of cerebral neurogenic vasodilation by L-glutamine and nitric oxide synthase inhibitors and its reversal by L-citrulline. J. Pharmacol. Exp. Ther. 276: 353-358.

Miguel, A., J.V. Maroto, A. San Bautista, C. Baixauli, V. Cebolla, B. Pascual, S. LópezGalarza, and J.L. Guardiola. 2004. The grafting of triploid watermelon is an advantageous alternative to oil fumigation. Scientia Hort. 103:9-17.

Muramatsu, Y. 1981. Problems on vegetable grafting [in Japanese]. Shisetu Engei. 10:48-53; 11:46-52.

Pogonyi, Á., Z. Pék, L. Helyes, and A. Lugasi. 2005. Effect of grafting on the tomato's yield, quality and main fruit components in spring forcing. Acta Aliment. 34:453-462.

Pulgar, G., G. Villora, D.A. Moreno, and L. Romero. 2000. Improving the mineral nutrition in grafted watermelon plants: Nitrogen metabolism. Biol. Plant. 43:607-609.

Robinson, R.W. and D.S. Decker-Walters. 1997. Cultural requirements, p. 113-143. In: Robinson, R.W. and D.S. Decker-Walters (eds.). Cucurbits. CAB International, Wallingford, UK.

Ruiz, J.M., A. Belakbir, I. López-Cantarero, and L. Romero. 1997. Leaf-macronutrient content and yield in grafted, melon plants. A model to evaluate the influence of rootstock genotype. Scientia Hort. 71:227-234.

Ruiz-Medrano, R., B. Xoconostle-Cbzares, and W.J. Lucas. 1999. Phloem long-distance transport of CmNACP mRNA: Implications for supracellular regulation in plants. Development 126:4405-4419.

Sakata, Y., O. Takayoshi, and S. Mitsuhiro. 2007. The history and present state of the grafting of cucurbitaceous vegetables in Japan. Acta Hort. 731:159-170.

Salam, M.A., A.S.M.H. Masum, S.S. Chowdhury, M. Dhar, M.A. Saddeque, and M.R. Islam. 2002. Growth and yield of watermelon as influenced by grafting. J. Biol. Sci. 2:298-299.

Satoh, S. 1996. Inhibition of flowering of cucumber grafted on rooted squash stocks. Physiol. Plant. 97:440-444.

Tiedemann, R. and U. Carstens-Behrens. 1994 Influence of grafting on the phloem protein patterns in Cucurbitaceae. I. Additional phloem exudates proteins in Cucumis sativus grafted on two Cucurbita species. J. Plant Physiol. 143:189-194.

Traka-Mavrona, E., M. Koutsika-Sotiriou, and T. Pritsa. 2000. Response of squash (Cucurbita spp.) as rootstock for melon (Cucumis melo L.). Scientia Hort. 83:353-362.

Trionfetti-Nisini, P.T., G. Colla, E. Granati, O. Temperini, P. Crino, and F. Saccardo. 2002. Rootstock resistance to fusarium wilt and effect on fruit yield and quality of two muskmelon cultivars. Scientia Hort. 93:281-288.

Xoconostle-Cázares, B., Y. Xiang, R. RuizMedrano, H.-L. Wang, J. Monzer, B.-C. Yoo, K.C. McFarland, V.R. Franceschi, and W.J. Lucas. 1999. Plant paralog to viral movement protein that potentiates transport of mRNA into the phloem. Science 283:94-98.

Xu, C.Q., T.L. Li, and H.Y. Qi. 2006. Effects of grafting on development, carbohydrate content, and sucrose metabolizing enzymes activities of muskmelon fruit. Acta Hort. Sinica 33:773-778

Xu, S.L., Q.Y. Chen, S.H. Li, L.L. Zhang, J.S. Gao, and H.L. Wang. 2005. Roles of sugarmetabolizing enzymes and $\mathrm{GA}_{3}, \mathrm{ABA}$ in sugars accumulation in grafted muskmelon fruit. J. Fruit Sci. 22:514-518.

Yamasaki, A., M. Yamashita, and S. Furuya. 1994. Mineral concentrations and cytokinin activity in the xylem exudate of grafted watermelons as affected by rootstocks and crop load. J. Jpn. Soc. Hort. Sci. 62:817-826.

Yetisir, H., N. Sari, and S. Yncel. 2003. Rootstock resistance to Fusarium wilt and effect on watermelon fruit yield and quality. Phytoparasitica 31:163-169.

Zhu, J., Z.L. Bie, Y. Huang, and X.Y. Han. 2006. Effects of different grafting methods on the grafting work efficiency and growth of cucumber seedlings. China Veg. 9:24-25. 